\title{
Gastric Inhibitory Polypeptide
}

National Cancer Institute

\section{Source}

National Cancer Institute. Gastric Inhibitory Polypeptide. NCI Thesaurus. Code C104432.

Gastric inhibitory polypeptide (153 aa, $\sim 17 \mathrm{kDa}$ ) is encoded by the human GIP gene. This protein plays a role in insulin secretion and glucose homeostasis. 